\title{
bioentrepreneur
}

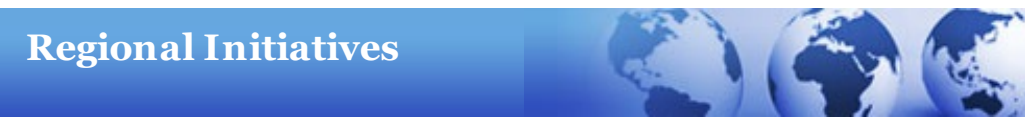

Published online: 10 November 2005, doi:10.1038/bioent891

Chile's supermodel

Veronica Guerrero 1

Veronica Guerrero is a freelancer in Mexico City

The government of Chile turns to a consortium of business leaders and academics to bolster its biotech prospects.

In an effort to better support its biotech industry, and foster a new generation of biotech startups in the process, Chile is turning to a network of technology businesses, entrepreneurs and academic leaders for help. The feeling in Santiago is that this network is in the best position to help provide startups with the capital and research talent that they require, and the partnering advice and connections that most biotech startups lack.

In years past, the government would have tried to manage such an effort through civil servants and existing bureaucratic structures. Not so this time. In this case, the government has offered to provide funding to qualified consortia of private and public companies and researchers.

Winning consortia were chosen not for their government connections, but rather for their R\&D focus, and the proven ability of

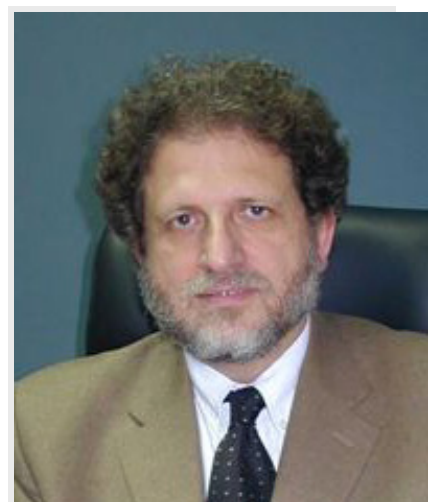

BPST

Consortium Connoisseur: BPST director Roberto Hojman

their members to deliver results. Each group pledged its own money to finance part of the project.

The consortia, also known as the Technological-Entrepreneurial Consortia of Research, was first envisioned about five years ago by the government, and now is part of the Chilean Bicentennial Program of Science and Technology (BPST) initiative. Using general funding from the World Bank, the BPST designated money for the project in 2003. The next year a surprisingly large number of proposals created a robust competition. Some 20 consortia applied to become part of the program. Nine were selected.

Each of the nine consortia is structured as a privately held company. In addition to the World Bank, they will be partly funded by the Chilean government through its National Commission of Scientific and Technological Research, and its Ministries of Economy and Agriculture. Large private companies have also invested, and expect royalties on commercialized products.

IfSeven of the nine selected were created to produce advances in agriculture or forestry production using biotechnology.y

Seven of the nine selected were created to produce advances in agriculture or forestry production using biotech, which says something about the importance of these two sectors-and of biotech-to the government of Chile these days. Within the agricultural consortia, the key focus is creating advances in the production of dairy products, avocados and grapes for wine making.

In 2004 , Chile exported $\$ 3.3$ billion worth of forestry products, $\$ 2$ billion worth of fruit, and $\$ 900$ million worth of wine. Chilean wines, which were virtually unknown outside of South America not long ago, now account for $5 \%$ of global wine exports. The government has the rather ambitious goal of becoming one of the world's top ten fruit exporters by 2010 .

Roberto Hojman, director of the BPST, says the Chilean government aims to provide the consortia with some $\$ 34.5$ million. Local firms like Concha $y$ Toro and outside investors like the Swiss food giant Nestle and Israel's Weizmann Institute have committed to investing an additional $\$ 11.5$ million 
during this time frame. Hojman believes that nongovernment investment in the consortia may increase in the coming years.

One consortium hopes to produce valuable biotech startups and intellectual property in addition to innovative products. This group, called the Consortium of Technological Research in Health, implemented an alliance among three Chilean universities and three private companies, among other entities. They plan to develop new markers and drugs to treat gastric and colon cancer, and hope new startups based on those products will arise.

GValenzuela had long urged the government to be more proactive about stimulating biotech R\&D in Chile, not least because of its potential to add new value to exports such as forest products and wine.y.

The government turned to Fundacion Ciencia para la Vida (Science for Life Foundation), a private nonprofit group that stimulates the use of biotech in Chilean industries. Pablo Valenzuela heads the foundation, and is a pioneer of biotech in Latin America.

Although Valenzuela's foundation will not participate in the funding or management of the consortia, it will play an active role in the R\&D activities connected with the initiative. Valenzuela had long urged the government to be more proactive about stimulating biotech R\&D in Chile, not least because of its potential to add new value to exports such as forest products and wine.

Valenzuela agrees that the consortia concept is a good one and that there are now legitimate reasons to be hopeful for biotech prospects in Chile. But, he also agrees that the consortia have a lot to prove. "While these developments are positive, and are heading down the right path," he says, "it is still necessary to fine tune the management of the consortia, increase the private sector's investment and involvement, and create more interaction with the countries that are most influential in biotechnology."

Although in the past, the Chilean government has usually left companies to fend for themselves, the new effort may not only support biotechs, but create new ones. And although only one of the nine consortia is designed to specifically create startups, they could be a byproduct of the project as a whole.

\section{Web links}

\section{Websites referenced:}

- National Commission for Scientific and Technological Research

- High Technology Investment Program

- Bicentennial Program of Science and Technology

- Foundation Science for Life

- Corporation for the Promotion of the Production

- Innova Chile

- Foundation Chile

\section{SPRINGER NATURE}

(c) 2019 Nature is part of Springer Nature. All Rights Reserved.

partner of AGORA, HINARI, OARE, INASP, ORCID, CrossRef, COUNTER and COPE 